\title{
The Protection of Human Rights in the European Union and the Perspective of the EU's Accession to the ECHR
}

Andrei Emil Moise"

Universitary Assistant, $\mathrm{PhD}$, Hyperion University of Bucharest, Romania

DOI: $10.36348 /$ sijlcj.2020.v03i07.003

| Received: 10.07.2020 | Accepted: 18.07.2020 | Published: 28.07.2020

*Corresponding author: Andrei Emil Moise

\section{Abstract}

The European Union has always stated its commitment to human rights and over the time has managed to bring this issue to the forefront, including in its relations with other states. It has introduced in its economic and trade agreements a clause expressly stipulating that the respect for human rights is an essential element of relations between the parties. With the entry in force of the Treaty of Lisbon, the Charter of Human Rights acquired binding legal force. So, the possibility of the European Union's accession to the European Convention for the Protection of Fundamental Rights and Freedoms and the ways in which it could be put into practice were discussed again. But in the context of accession, the questions arise as to how the two jurisdictional institutions can coexist, namely the European Court of Human Rights and the Court of Justice of the European Union, what relationship will develop between them and what mechanisms need to be developed for both the Charter and the Convention can be applied.

Keywords: European Union, The Charter of Fundamental Rights of the European Union, European Convention on Human Rights, The Court of Justice of European Union, European Court of Human Rights.

Copyright @ 2020: This is an open-access article distributed under the terms of the Creative Commons Attribution license which permits unrestricted use, distribution, and reproduction in any medium for non-commercial use (NonCommercial, or CC-BY-NC) provided the original author and source are credited.

\section{INTRODUCTION}

"The purpose of law is the good of society and justice and human will acquires legal meanings only when it has a moral determination, ethics, good faith, harmonized with the general interest of society" [1].

"Human rights are the foundation of human existence and coexistence. Universal, indivisible and interdependent, they define humanity. They embody the principles that form the cornerstone of human dignity", said the UN General-Secretary in his speech at the $50^{\text {th }}$ anniversary of the adoption of the Universal Declaration of Human Rights.

"In any system of law based on democratic principles, any party to a legal relationship, including when this is a state authority, has an obligation to adopt a conduct that does not harm human dignity or the rights and freedoms of the citizens" [2].

The task of protecting human rights belongs to the judiciary system and involves the control of governmental action [3].
The European approach of the human rights is the broadest existing approach at international level in the field of fundamental human rights, the European concept being characterized by a number of specific features. The protection of the rights at European Union level is ensured by efficient regional intergovernmental mechanisms.

For decades, there has been an attempt to place human rights within the framework of European cooperation at community level. Thus, the process of recognizing and protecting human rights has taken a double evolutionary path in Europe, in the sense that, on the one hand, an attempt has been made to enshrine them in the rules of community law, and on the other hand, the Court of Justice of the European Communities has played a key role in enforcing them in existing policies at community level.

\section{RESEARCH METHODS}

The author approached this topic considering that "the research can contribute to the enrichment of legal doctrine, to optimize the knowledge process in this field and, obviously, to the use in practice of the ideas expressed" [4]. 
"Personal contribution is found throughout the paper and is highlighted by the way in which the used concepts were analyzed, by the way in which the doctrinal opinions submitted to attention were argued, by the personal opinions and the conclusions formulated" [5].

The author used established research methods: documentation method, comparative method, analytical method, the logical method, examination of judicial practice or application method.

\section{DISCUSSIONS AND RESULTS}

\section{Charter of Fundamental Rights of the EU - History of Appearance and its Status before the Lisbon Treaty}

Initially, there was no provision in the treaties concerning the European Communities similar to the one existing in the text of Article 38 (1) of the Statute of the International Court of Justice. In addition, the pressure of national jurisdictions was extremely strong. However, even in this difficult context, with a cautious attitude at first, the Court of Justice of the European Communities has managed to develop a set of decisions, which should be the starting point for the protection of fundamental rights in the European Economic Community. This set of decisions has managed to be fully in line with both the community legal order and the national legal order of the Member States.

Over the time, the Court of Justice of the European Communities, based on clear interpretation techniques, has developed an extremely organized and very rigorously substantiated case law. This has ensured an "efficient protection" of human rights at community level [6]. The new situation has allowed to the Court to take a firm stand in the sense that the internal legal order of the Member States regarding the protection of human rights is subjected to the "preeminence of community logic" [7]. So, "the protection of human rights in the European Community and in the European Union has developed in a case-law manner, human rights being protected by the community judge as general principles of community law" [8].

The attributions of the Court of Justice of the European Communities include the analysis of two categories of national actions, namely those relating to the transposition of community provisions into national law and those involving exceptions or derogations from community policy granted to the Member States. But the Court's scrutiny was carried out a posteriori, forcing the Member States to legislate in accordance with respect for fundamental human rights.

The Charter of Fundamental Rights of the European Union is a legal innovation and also an innovation for the policy of European integration and is due to the initiative of Germany. The European Council held in Cologne, Germany, on June 3-4, 1999 decided to draw up this document and to proclaim it at the European Summit in Nice on the $7^{\text {th }}$ of December 2000. Member States have expressed a desire to develop a genuine community policy on fundamental rights: it is a matter of humanizing the Union [9].

Nicole Fontaine, the President of the European Parliament, in her statement from the 14th of March 2000 said that the Charter seeks to affirm some essential principles in the field of community law and it is the first document adopted at European level to unify fundamental values of European societies. The document covers civil, political, economical and social rights, which are comprehensively addressed, establishing an increasingly close link between Member States, based on common values, such as human dignity, freedom, equality, solidarity, in order to ensuring a peaceful future. It could be stated that the titles of the Charter, seven in number, constitute an element of "modernity", if it is considered that the classical differentiation of rights into civil, political, economic and social rights is no longer used [10]. International law in matter of human rights distinguishes three generations of rights, namely "civil and political rights (first generation); economical, social and cultural rights (second generation); so-called solidarity rights (third generation)" [11].

The Charter states that the European Union is established with respect for the principles of democracy and the rule of law, with respect for the national identity, culture and traditions of the Member States, in order to create an area of freedom, security and justice. The human being is a key concern of the Union, for this reason strengthening the protection of fundamental rights, establishing European citizenship and ensuring the free movement of persons, services, goods and capital, as well as the freedom of establishment.

"The European citizenship is a complex concept, because it brings together local, national and supranational elements, ideally symbolizing the communion of goals and means that exist between the peoples of the Member States of the European Union" [12]. As it was stated in the Preamble to the Charter, it seeks to reaffirm the rights "which result mainly from the constitutional traditions and international obligations common to the Member States, form the European Convention for the Protection of Human Rights and Fundamental Freedoms, from the Social Charters adopted by the Union and by the Council of Europe, as well as from the case law of the Court of Justice of the European Union and from the case law of the European Court of Human Rights". Maybe that's why many saw this document as the first step in a European constitution or even the cornerstone of a possible federal Europe. 
Although it was not directly recognized as having a binding legal force, the Charter has nevertheless proved its applicability from the beginning at political and legal level. At political level, because all Member States have an obligation to take its provisions into account in both drafting and the application of national law, as well as in the relations that arise at interstate level. At legal level, because it constitutes an essential landmark for the jurisprudence of the European Court of Justice and at the same time it makes possible the intervention of the Court of Justice of the European Communities regarding the protection of human rights. However, it must be emphasized that it has generated a number of uncertainties regarding its status, role, functions, as well as regarding the institutions that were to ensure its efficiency. Also regarding its legal status the discussions were extremely heated. In this regard, it was considered that "one of the few unambiguous statements that can be made about the legal status of the Charter is that its current legal status is unclear" [13].

"The Charter is a political document with a vocation to irrigate and animate the life and institutions of the Union, a step towards the constitutionalizing of the Union as a democratic political ensemble" [14].

\section{The Application Field of the Charter}

As it results from Article 51, the scope of the Charter concerns the institutions, bodies, offices and agencies of the Union, in accordance with the principle of subsidiarity and with the Member States only in so far as they implement the rules of Union law. It also follows from Article 52 that any restriction on the exercise of the rights and freedoms recognized by this document must be legally regulated and respected the substance of those rights and freedoms. In principle, with the exception of a few rights, such as those provided for in Title V (Citizens' Rights) or those relating to free movement and freedom of residence, almost anyone can enjoy the fundamental rights recognized in the Charter, whether or not they are nationals of Member States.

\section{Configuration of Post-Lisbon Fundamental Rights}

The Treaty of Lisbon, also known as the "Reform Treaty", entered into force on the $1^{\text {st }}$ of December 2009, this moment being a milestone in the history of the evolution of the European Union. The Charter of Fundamental Rights of the European Union helps to support the Union's aspirations, which are reflected in the Treaty of Lisbon. By ratifying the Treaty of Lisbon, the Charter of Fundamental Rights of the European Union acquires binding legal force, giving to all the rights contained in the Charter a greater legal protection.

The High Representative of the European Union for Foreign Affairs and Security Policy, Catherine Ashton, said: "The Lisbon Treaty gives us the possibility for a much more coherent EU foreign policy, including on human rights issues. But the world is also changing outside the European Union. We also need to ask ourselves what we could do better. We can not do everything on our own. Our partnership with civil society organizations remains more than ever an essential component of our policy in the field of human rights".

Belgian Foreign Minister Steven Vanackere added: "The Lisbon Treaty has brought substantial changes and paves the way for strengthening the EU's role in promoting and protecting human rights. This Forum focuses on European policy instruments on the promotion of human rights. We welcome the large number of NGOs from around the world coming to this important event and look forward to their recommendations".

The European Commission aims to implement a strategy with a role in monitoring compliance with the content of the Charter, a strategy based on three main pillars. The first pillar aims to ensure respect for fundamental rights within the Union and involves strict monitoring of the process of implementing the Charter's provisions in the national legislation of the Member States, and this monitoring is done by the Commission itself. "In order to maintain and strengthen the rule of law, the legislator must comply with the lawmaking procedure, not exceed its powers and take into account that any legal rule must be harmoniously integrated in the context of existing ones" [15]. The second pillar aims to ensure that citizens are informed as efficiently as possible about the fundamental rights recognized to them, as well as about the possibility of exercising legal remedies in case of need. The third pillar provides for the preparation of annual reports monitoring the progress made in implementing the provisions of the Charter.

Viviane Reding, European Commissioner for Justice, Fundamental Rights and Citizenship, emphasized: "The Charter must cover all EU policies. The European Commission, and in particular its Justice Department, will be very vigilant in ensuring that the provisions of the Charter are complied with in all EU legislative proposals, in all amendments introduced by the Council and the European Parliament, and by Member States when implement EU law. The strategy adopted by the Commission today is an important step in creating the European culture of fundamental rights".

Since the provisions of the Charter are incidental to all existing institutions at Union level and to the Member States, in the event that the latter apply community law, any citizen within the Union may apply to the Court of Justice of the European Union in case of non-compliance with the rights set out in the Charter. 
It should be noted that both the application and compliance with Union law are carried out in the first stage at Member State level. Thus, based on the principle of sincere cooperation, in accordance with Article 4(3) of the Treaty on European Union, it is for the Member States to take the necessary measures to fulfill their obligations under Union law. In accordance with Article 19 of the same treaty, it is imperative that Member States ensure the remedies inherent in efficient legal protection in the area of interest of legal regulations adopted at European Union level. The Court of Justice of the European Union is the guarantor of the rule of law of the European Union. It has jurisdiction, by way of a preliminary ruling procedure, to rule on aspects of the interpretation of European Union rules when a national court so requests in the scope of the uniform application of Union rules [16]. Also, a person concerned "directly and individually" [17] by a document adopted at European Union level, if he proves this, has the possibility to request an examination of the legality of those documents by promoting an action for annulment.

Although "there is legislation in the European Union that protects [...] and, at the same time, there are additional references that mention how human rights are respected in the accession or integration countries", and "a number of resolutions, which are true, without binding legal force, were issued by the European Parliament in the field of human rights", it is very true that, at the beginning, the Treaties of the European Community did not regulate fundamental rights, but a series of provisions with similar content existing in the Constitutions of the Member States, as well as a series of provisions of the European Convention on Human Rights, elevated to the rank of fundamental principles of European Union law, are found in the decisions of the Court of Justice of the European Union assimilated to fundamental rights [18]. As the author pointed out previously, the European Charter of Fundamental Rights [19] is the first document that brings together the fundamental human rights in a common framework to all the Member States of the Union. These rights were recognized to both citizens of Europe and those residing in the European Union. They were grouped into six chapters, namely Dignity, Freedoms, Equality, Solidarity, Citizenship and Justice. The document has gained legal binding force since December 2009, while being the primary legislation of the Union.

Regarding the Preamble of the Charter, the doctrine expressed the view that it would represent an "extremely complex combination of sources, reservations and considerations, in which the Court of Justice, the Court of First Instance and the special courts referred to generically by the Treaty, as well as the national courts will have to find the basis for interpreting the Charter and substantiating their decisions" [20].
It is to be noted in the Charter that sometimes the term "rights" is not used, but that of "principles" [21] is. In such circumstances the courts of the Member States will be able to invoke these principles only for the purpose of interpreting and deciding on the legality of the acts of the institutions, bodies, offices and agencies of the Union and of the Member States implementing EU law [22]. Regarding the obligations set out in the Charter, they become incident only if Member States act "within the scope of EU law" [23]. The case law of the Court of Justice of the European Union attests the fact that the meanings of the terms "implementation" and "within the scope" are the same [24], which is particularly relevant for the circumstances in which Union directives and regulations are implemented by the Member States [25].

As European law becomes more and more harmonized we should ask ourselves whether the fundamental rights in national constitutions will have any real power in the future [26].

In the light of the negotiations on a possible accession of the European Union to the European Convention on Human Rights, it is particularly important that all Member States of the Union are signatories to the Convention, as when the provisions of the Charter cannot be applied, there are chances that the Convention's provisions to be incidental.

"Developed within the Council of Europe and adopted on the $4^{\text {th }}$ of November 1950, the Convention for the Protection of Human Rights and Fundamental Freedoms [27] has become one of the most important and effective legal instruments in the world in the field of protecting human rights, not only through its many rights and freedoms recognized and guaranteed, but also through its established procedure" [28]. The Convention for the Protection of Human Rights represents "the first instrument of international law that has organized the defense of the individual before his own state, guaranteeing his fundamental rights and freedoms" [29].

\section{Issues on Possibility of Accession}

With the entry into force of the Lisbon Treaty, the possibility of the European Union's accession to the European Convention for the Protection of Fundamental Rights and Freedoms and the ways in which it could be put into practice were discussed again. So, on the 17th of March 2010, The European Commission proposed negotiating directives in this regard. A statement from the European Commission states that "the Lisbon Treaty contains the legal basis for the EU's accession to the ECHR", the Convention being considered to be the expression of the most important document designed to ensure the protection of human rights and fundamental freedoms in Europe. The legal basis are the provisions of the Protocol detailing the institutional and material aspects to be taken into account during the negotiations 
and also the provisions of article 6 par. 2 TEU in accordance with which "the Union shall accede to the European Convention for the Protection of Human Rights and Fundamental Freedoms. The competences of the Union, as defined in the Treaties, are not altered by this accession".

Protocol no. 14 of the Convention, adopted in 2004 and entered into force on June 1, 2010, amends Article 59 of the Convention, so that the EU can accede to it. On the $6^{\text {th }}$ of June 2010, it was adopted the decision of the EU Council to authorize the beginning of the negotiations with the Council of Europe in the scope of the EU's accession to the ECHR and to approve the negotiating directives. The draft agreement on the accession of the European Union to the European Convention on Human Rights was adopted on the $18^{\text {th }}$ of March 2011. The negotiations were finalized on the $5^{\text {th }}$ of April 2013, and three months later, on the $4^{\text {th }}$ of July 2013, the European Commission requested the Court of Justice of the European Union for an opinion on the compatibility of the draft agreement with the Treaties of the Union.

On the $18^{\text {th }}$ of December 2014, the Court ruled that in its current wording, the expected agreement on EU accession to the ECHR is incompatible with both Article 6 par. 2 of the TEU, as well as with Protocol no. 8 regarding Article 6(2) of the Treaty on European Union. It must be specified the fact that, according to the provisions of Article 218 par. 11, second sentence of the TFEU, "in the event of a negative opinion of the Court, that agreement may enter into force only after its amendment or after the revision of the Treaties". The Court also considered that the accession should be made in compliance with the principle of mutual trust between Member States in Union law. In the event of disputes arising either between Member States or between Member States and the Union over the application of the European Convention in the substantive field of Union law, their resolution should not fall within the competence of the European Court of Human Rights. The Court stated too that the accession also requires compliance with the specific features of Union law as regards the judicial review of acts, actions or omissions in the field of the Common Foreign and Security Policy (CFSP). From this perspective, it was appreciated, "the hierarchy is replaced by alternation, subordination by coordination, linearity by interaction, confrontation by coexistence, opposition by reciprocity and adaptation", the idea of uniformity being replaced by conciliation and harmonization [30].

\section{Considerations on the Implications of the European Union's Accession to the Convention of the Protection of Human Rights and Fundamental Freedoms}

Looking at the history of its case-law, it is to be noticed that the Court of Justice of the European Union, then the Court of Justice of Economic
Community, seemed to reject the principle of respecting the human rights and fundamental freedoms, since it has ruled that there are no principles in community law which guarantee respect for human rights [31]. Subsequently, the Court's position was changed, acknowledging that community law also recognizes rights, in addition to the obligations imposed, rights that must be respected by the national courts of the Member States [32]. Moreover, in another judgment [33], the Court held that "the fundamental rights are an integral part of the general principles of law, whose respecting is ensured by the Court; the protection of these rights, which are inspired by the constitutional traditions common to the Member States, must be ensured within the structure and objectives of the Community". Also Stauder judgment - a "famous obiter dictum" is a benchmark in this regard [34]. An extremely important milestone in its jurisprudential development is the ruling that international treaties on fundamental rights to which the Member States are parties may provide guidance to be taken into account in the field of community law [35].

This recognition made for the purpose of interpreting Community rules by reference including to the European Convention on Human Rights, should be seen as the first step of the Court of Justice of the European Communities in cooperating with the European Court of Human Rights. Moreover, the Court has acknowledged that where there is a conflict between the rules of Union law and the protection of a right, on the basis of a non-uniform regulation of that right in the national law of the Member States, community law will be interpreted in such a way that the essence of that right to be protected [36]. On the other hand, in a case alleging a violation of a right recognized in the European Convention on Human Rights, the Court of Justice of the Economic Community has declined its jurisdiction competence. It is about of the right to expression, recognized in the general Community principles, but the Court has argued that it has no jurisdiction over the internal acts of the Member States which go beyond the scope of community law [37].

It is important to specify the position of the European Court of Human Rights, which was called upon to rule in a case similar to the latter to which the author referred. The European Court has ruled that the right to information is a component part of the freedom of expression, regardless of the impact of that information on the population, and that the restriction of the right to express violates the provisions of Article 10 of the Convention when it is disproportionate to the purpose pursued, in this case the scope being to protect morality [38].

Therefore, if the same rights continue to be under the jurisdiction of both the Court of Justice of the European Union and the European Court of Human Rights, this situation creates the risk of divergence, 
obviously with harmful effects, as this could lead to a multiplication of already existing cases of different jurisprudential interpretation regarding their content. By this it must not to be understood that there are conflicts between the two international courts, because they recognize and, at the same time, respect both their existential status and the legal order, on the background of a tendency to approach from a jurisprudential point of view. Moreover, representing two different international organizations, between the two courts have even developed mechanisms for collaboration and cooperation, although their procedures are different.

The author expresses the opinion that, by virtue of their essential importance in the two legal systems that they represent and which are under their jurisdiction, both the European Court of Human Rights and the Court of Justice of the European Union are trying to achieve a transitional system until at the time of accession. The author's assertion in this regard is based on a decision [39] of the European Court, in which it admits that it respects and recognizes the existence of the legal system of the Court of Justice of the European Union. Here it is highlighted that the latter also has jurisdiction in the field of protection of human rights, but also the limits within which it itself has the power to exercise control over it. Therefore, it can be said that this judgment has the effect of resizing the existing relations between Union law and conventional law. Is this decision the moment that would mark the recognition of the possibility that acts of Union law may be subject to judicial review by the European Court of Human Rights? Or, in other words, should this be the moment when the ECHR acquires jurisdiction over the CJEU, with the simultaneous loss of the presumption of European parallelism in the exercise of jurisdiction?

In author's opinion it can be said that, with the entry into force of the Treaty of Lisbon, the preconditions for the transformation of the Court of Justice of the European Union into a Court of Human Rights have been created. The opinion is also based on the fact that, in addition to some fundamental principles set out in the Charter, others have been taken from the very text of the Convention on Human Rights. The two documents should be regarded as situated in a relationship of coexistence, both of which have the role of complementing each other, without contradicting each other. There are several ways in which the content of the European Convention on Human Rights is received by the Charter of Fundamental Rights: loans, adoption of rules, simplifications or updates thereof being just a few of them, based on Article 51 of the Charter that obliged both institutions and bodies, but also the Member States when "apply the law of the Union" to respect its provisions [40].

It is true that at European level there is a parallelism both in terms of regulations and in terms of institutions, as the Court of Justice of the European Union ensures compliance with Union law by the European Union and the European Court of Human Rights compliance with the provisions of the Convention by the member states of the Council of Europe. Therefore, regarding the human rights, the Court of Justice of the European Union penalizes breaches of the rights and freedoms set out in the rules of Union law, in particular those contained in the Charter, and the European Court of Human Rights, by the decisions ruled in the cases of violation of the Convention, as well as by the authority of these decisions, determines normative changes in the internal law of the member states of the Council of Europe. The determination of regulatory changes in the domestic law of the Member States should not be construed as an action by which "the sovereignty of the Member States of the European Union will be affected, as the CJEU itself ruled in Case C-41/1974, Yvonne van Duyn v. Home Office, that member countries have the freedom to decide on "the requirements of their public order" and according to "their national conception", as well as to decide on the limits of interference in accordance with the legitimacy of the aim pursued" [41]. Therefore, the author subscribes to the opinion expressed in the doctrine according to which "the judicial practice in the field of human rights has been the object of concern and is in the attention of scientific research, but also retains the attention of the legislative authorities of each state" [42].

A very important question is what will happen to this parallelism in the event of the European Union's accession to the ECHR? The optimistic people hope in the cooperation in accordance with the principle of complementarity between the Court of Justice of the European Union and the European Court of Human Rights, cooperation ensured by a modern legal framework created by the future Accession Treaty. Currently, anyone whose rights under the Convention have been violated may bring an action against the states of which they are nationals. By analogy, theoretically at least, as the effect of accession, any person whose rights under the European Convention have been infringed by an action or, conversely, by an inaction of the institutions of the Union, should be able to promote an action against the Union, seeking redress for the damage caused to the European Court of Justice. In this case, indisputably, the Court of Justice of the European Union will lose its current values, and will behave like all other supreme jurisdictions existing at the level of the Member States. Like the other national courts, it will be called upon to apply "national law", in this case community law, as well as the provisions of the Convention in the same spirit as the interpretation given to them by the European Court [43]. Therefore, the European Court of Human Rights will certainly be in a higher position than the Court of Justice of the Union. Practically, this collaborative relationship between the two jurisdictions 
will be extinguished, and the European Court, as a specialized court with jurisdiction only in the field of human rights protection, will subordinate the other. Even in a vision of jurisdictional pluralism, it is difficult to assess whether it would still be possible to maintain a coexistence of the two institutions in terms of complementarity and interdependence. In fact, Viviane Reding, Vice-President of the European Commission and Commissioner for Justice, Fundamental Rights and Citizenship, said that "by accession, the European Union reaffirms the central role of the European Convention in the field of human rights protection, ensuring, formally and completely, that its order lies within this system". "Adherence to the ECHR is of political, legal and symbolic importance" said President José Manuel Barroso. "The EU's accession to the European Convention on Human Rights will provide a coherent system of protection of fundamental rights throughout the continent and will complement the level of protection established by the Lisbon Treaty through the Charter of Fundamental Rights, which has binding legal force".

It is for sure that the EU's accession to the Convention will significantly increase the level of protection of fundamental rights, as accession will also allow the unification of jurisprudence in this field throughout Europe. In fact, according to Declaration 2 annexed to the Lisbon Treaty, it is to be noted "the existence of a constant dialogue between the Court of Justice of the European Union and the European Court of Human Rights (...)", in the sense that the current case law of the first one takes into account the case law of the latter. The legal value of the Charter is similar to the legal value of the treaties, which is particularly important as this is both a legal and a political expression in the sense of ensuring the most effective protection of human rights in Europe.

Of course, the accession of the European Union to the ECHR will increase judicial control over respect for fundamental human rights and freedoms at the level of the European Union. This will happen as a result of extending the control to the institutions, bodies and agencies of the European Union and also to the Court of Justice of the European Union, at least in the field of compliance with the rules contained in the European Convention on Human Rights. "These categories of rights are the most often susceptible to abuse and, at the same time, the most representative due to their frequency and their severity of the consequences both at the international interstate level and at the level of the citizens of that state"[44]. For this reason, the author considers that it is very important to make it possible to redress for the damage caused to all those whose human rights have been violated by the European Union, by granting them the right to promote such actions, after all legal remedies have been exhausted at national level.
As a result of a possible accession of the European Union to the ECHR, the credibility of the Union's system regarding human rights will gain further value, as the Union itself demonstrates to the world that it attaches importance to the European system of protection of fundamental rights. The credibility of the Union's foreign policy will also be resized.

Discussed and evoked since the late 1970's, the accession of the Union to the provisions of the European Convention on Human Rights became a principle enshrined in the Treaty on European Union and a legal obligation, by the entry into force of the Treaty of Lisbon on the $1^{\text {st }}$ of December 2009. It is considered a solution to ensure the efficiency of the conventional system, by achieving uniformity in the application and interpretation of provisions with similar content, included in the two European reference documents, namely the Charter of Fundamental Rights of the European Union and the European Convention on Human Rights. Given that, in the light of the decision of the Court of Justice of the European Union, the European Commission continues to take steps to make accession possible, the EU could still become the 48th Contracting Party to the Convention, without being a member of the Council of Europe.

\section{CONCLUSIONS}

The implications and consequences of such accession are multiple and will manifest both on the interpretation of the rules set out in the Charter and the Convention, and on the desired relationship of complementarity between the two jurisdictions. Of course, this report will gain new value and the Charter would no longer be an alternative to the Convention, but would effectively become a complement to it. In author's opinion, only in this way the danger of creating standardization in a double way of ensuring the respect for fundamental human rights in the space of the old continent can be avoided.

As the author shown in this study, full accession will practically subordinate the Court of Justice of the European Union to the European Court of Human Rights, and this is not desirable. Therefore, the author considers it is essential for the achievement of accession, the elaboration by the European Commission of a framework on the modalities of collaboration and cooperation between the jurisdictional authorities at European level.

\section{REFERENCES}

1. Nour, A. (2018). Theoretical and Practical Consideratons Regarding the Power Abuse. Proceeding of the International Conference of Law, European Studies and International Relations. Bucharest: Hamangiu S.R.L. Publishing House. VI, 627. Available on 
https://www.ceeol.com/search/article-

detail?id=826452

2. Nour, A. (2020). Chemical Castration of the Sexual Offender versus Human Fundamental Rights and Freedoms. Scholars International Journal of Law, Crime and Justice. Dubai: Scholars Middle East Publisher. 3(5), 144. DOI: 10.36348/sijlcj.2020.v03i05.002. Available on https://saudijournals.com/sijlcj

3. Cappelletti, M. (1971). Judicial Review in the Contemporary World. Bobbs-Merril Publishing House. In Schutze, R. (2012). Dreptul constituţional al Uniunii Europene. Bucharest: Editura Universitară.

4. Nour, A. (2018). Corruption - Aggravated Cause of Violations of the Rule of Law. Current Issues in Business Law Contributions to the $8^{\text {th }}$ International Conference Perspectives of Business Law in the Third Millennium. Bucharest: ADJURIS International Academic Publisher. 158. Available on

http://www.adjuris.ro/reviste/ciibl/Current\%20Issu es\%20in\%20Business\%20Law.pdf

5. Nour, A. (2019). The Crime of Traffic of Influence in the New Incrimination Formula. Perspectives of Law and Public Administration. Bucharest: ADJURIS - International Academic Publisher. 8(2), 358. Available on http://www.adjuris.ro/revista/articole/an8nr2/25.\% 20Andrada\%20Nour\%20$\% 20$ Lucrarea\%20nr.\%202.pdf

6. Shaw, J. (1996). Law of the EU. MacMilan Law Masters. 190.

7. Picod, F. (1998). Le juge communitaire et l'interprétation européenne. In Sudre, F. (coord.) (1998). L' interprétation de la CEDO. Droit et justice no. 21. Bruxelles: Bruyant. 289.

8. Miga-Beșteliu, R., \& Brumar, C. (2008). Protecţia internaţională a drepturilor omului, Note de curs, Ed. a IV-a revizuită. Bucharest: Universul Juridic Publishing House. 78.

9. Renucci, J.F. (2009). Tratat de drept european al drepturilor omului. Bucharest: Hamangiu Publishing House. 24.

10. Sudre, F. (2006). Tratat de drept european al drepturilor omului. Bucharest: POLIROM Publishing House. 127.

11. Corlăţean, T. (2012). Protecţia europeană şi internaţională a drepturilor omului. Bucharest: Universul Juridic Publishing House. 59.

12. Ispas, G.L. (2012). Uniunea Europeană. Evoluție. Instituţii. Mecanisme. Bucharest: Universul Juridic Publishing House. 49.

13. Mc Crudden, C. (2001). The Future of EU Charter of Fundamental Rights. Common Market Law Review no.10. 10.

14. Dutheil de la Rochère, J. (2001). Droits de l'homme. La charte des droits fondamentaux et au delà. Paris. 2. Available on
Www.jeanmonnetprogram.org/papers/01/013501.h tml

15. Nour, A. (2018). Legal Interpretation Connection between the Letter and Spirit of the Law. Proceeding of the International Conference of Law, European Studies and International Relations. Bucharest: Hamangiu S.R.L. Publishing House. VI, 614. Available on https://www.ceeol.com/search/articledetail $? \mathrm{id}=826450$

16. Treaty on the Functioning of the European Union, Article 267, OJ C 326 (2012).

17. Treaty on the Functioning of the European Union, Article 263 (4), OJ C 326 (2012); to see in this regard CJEU (2013), C-583/11 P, Cause Inuit Tapiriit Kanatami et al v. European Parliament and European Union Council.

18. Nour, A. (2016). Ocrotirea libertăţii sexuale şi de orientare sexuală a persoanei la nivel european şi internaţional. Proceeding of the International Conference of Law, European Studies and International Relations. Bucharest: Hamangiu S.R.L. Publishing House. IV, 562. Available on https://www.ceeol.com/search/articledetail $? \mathrm{id}=824720$

19. Charter of Fundamental Rights of the European Union OJ C 326 (2012); to see also Article 6(1) of The Treaty of European Union

20. Diaconu, I. (2009). Protecţia drepturilor omului în cadrul Uniunii Europene. "Revista Română de Drept Comunitar" no. 1.

21. For example, Article 23 refers to the principle of equality between men and women.

22. To see in this regard Article 52 (5) of the Charter of Fundamental Rights of the European Union

23. Explanations on the Charter of Fundamental Rights of the European Union (2007/C 303/02)

24. To see in this regard CJEU 2013/C-617/10 REC, Cause Akklagaren v. Hans Åkerberg Fransson, par. 17-21.

25. To see in this regard CJEU 2014/C-206/13, Cause Cruciano Siragusa v. Regione Sicilia Soprintendenza Beni Culturali e Ambientali di Palermo, par. 24-25.

26. Nergelius, J. (2015). The EU Accession to the European Convention on Human Rights. Stockholm: Swedish Institute for European Policy Studies Publishing House, Report. 3:28-35.

27. It is known under simplified name as European Convention on Human Rights.

28. Nour, A. (2017). International legal instruments on the protection of sexual freedom of the person essential component of the right to private life. Proceeding of the International Conference of Law, European Studies and International Relations. Bucharest: Hamangiu S.R.L. Publishing House. $\mathrm{V}, 275 . \quad$ Available on https://www.ceeol.com/search/articledetail $? \mathrm{id}=825059$ 
29. Predescu, O., \& Udroiu, M. (2007). Convenţia europeană a drepturilor omului şi dreptul procesual penal român. Bucharest: C.H. Beck Publishing House. 14.

30. Tulkens, F., \& Callewaert, J. (2002). Le point de vue de la Cour Européenne des Droits de l'Homme. In La Charte des droits fondamentaux de l'U.E. (son apport à la protection des droits de l'homme en Europe). Bruxelles: Bruyant. 239.

31. To see in this regard Decision of the Court from the $15^{\text {th }}$ of July 1960 in Cause 40/59 Entreprise I. Nold KG v. High Authority of the European Coal and Steel Community, The Collection of Jurisprudence of CJEU, English Special Edition, 423.

32. To see in this regard Decision of the Court from the $5^{\text {th }}$ of February 1963 in Cause 26/62 NV Algemene Transport - en Expeditie Onderneming van Gend \& Loos c. Administration fiscale néerlandaise, The Collection of Jurisprudence of CJEU,1963, French Edition, 3.

33. To see in this regard Decision of the Court from the $17^{\text {th }}$ of December 1970 in Cause 11/70, Internationale Handelsgesellschaft $\mathrm{GmbH} c$. Einfuhr und Vorratsstelle fur Getreide und Futtermittel, The Collection of Jurisprudence of CJEU, 1970, French Edition, 1125.

34. Tizzano, A. (2011). Protecţia drepturilor fundamentale: principala contribuţie a Curţii Europene de Justiţie la evoluţia constituţională a UE. "Revista Română de Drept European" 6:30.

35. To see Decision of the Court from the $14^{\text {th }}$ of May 1974 in Cause 4/73, J. Nold, Kohlen and Baustoffgroßhandlung v. Commission of the European Communities (Nold II), The Collection of Jurisprudence of CJEU, 1974, French Edition, 491.

36. To see in this regard Decision of the Court from the $13^{\text {th }}$ of July 1989 in Cause 5/88 Wachauf v.
Bundesamt für Ernährung und Forstwirtschaft, The Collection of Jurisprudence of CJEU, 1989, 2609.

37. To see in this regard Decision of the Court from the $4^{\text {th }}$ of October 1991 in Cause 159/90, Society for the Protection of the Unborn Child v. Stephen Grogan et al, The Collection of Jurisprudence of CJEU, 1990, I-4685.

38. To see in this regard Open Door \& Dublin Well Woman v. Ireland (ECHR, the $29^{\text {th }}$ of October 1992).

39. To see in this regard Bosphorus Airways v. Ireland App no 45036/98, ECHR, the $30^{\text {th }}$ of June 2005.

40. Tulkens, F., \& Callewaert, J. (2002). Le point de vue de la Cour Européenne des Droits de l'Homme. In La Charte des droits fondamentaux de l'U.E. (son apport à la protection des droits de l'homme en Europe). Bruxelles: Bruyant. 239.

41. Nour, A. (2019). Current conceptual references regarding fraud to law and public order in the field of private international law. Proceeding of the International Conference of Law, European Studies and International Relations. Bucharest: Hamangiu S.R.L. Publishing House. VII, 545. Available https://www.ceeol.com/search/articledetail?id=828328

42. Nour, A. (2016). Dimensiunea și limitele dreptului la viaţa privată în practica judiciară international. Revue Europeenne du droit social, Suppliment. Bucharest. 154.

43. Tulkens, F., \& Callewaert, J. (2002). Le point de vue de la Cour Européenne des Droits de l'Homme. In La Charte des droits fondamentaux de l'U.E. (son apport à la protection des droits de l'homme en Europe). Bruxelles: Bruyant. 234.

44. Nour, A. (2019). De la litera legii la destabilizarea ordinii de drept. Bucharest: C.H. Beck Publishing House. 78. 